\title{
Conceptual Design of Arecanut Sheath Shredder
}

\author{
Shashikumar*, D.J. Shrinivasa, M. Anantachar and M. Veerangouda \\ Department of Farm Machinery and Power Engineering, CAE, University of Agricultural \\ Sciences, Raichur, Karnataka, India \\ *Corresponding author
}

\begin{tabular}{|c|c|}
\hline & A B S T R A C T \\
\hline Keywords & \multirow{4}{*}{$\begin{array}{l}\text { The arecanut sheath shredder has been designed for chopping of arecanut sheath } \\
\text { into small pieces suitable for animal fodder. The arecanut sheath shredder consists } \\
\text { of cylindrical cutter head with knives and also having feed roller to gather, } \\
\text { compress and advance the arecanut sheath into the cutterhead. The shredder is } \\
\text { operated by an electric motor and power transmitted to the cylindrical cutterhead } \\
\text { through the shaft via the pulley's v-belt. It is manually fed with one sheath at a } \\
\text { time through the feeding chute. The whole sheath passes horizontally against the } \\
\text { rotating knives and become chopped into small pieces. The overall size of } \\
\text { arecanut sheath shredder was } 1000 \mathrm{~mm} \text { in length, } 500 \mathrm{~mm} \text { in width and } 780 \mathrm{~mm} \text { in } \\
\text { height. The arecanut sheath shredder units get power for motion from electric } \\
\text { motor mounted on bottom of the main frame. }\end{array}$} \\
\hline $\begin{array}{l}\text { Arecanut sheath, } \\
\text { Fodder, Cattles, } \\
\text { Arecanut palm. }\end{array}$ & \\
\hline Article Info & \\
\hline $\begin{array}{l}\text { Accepted: } \\
\text { 17 September } 2017 \\
\text { Available Online: } \\
10 \text { October } 2017\end{array}$ & \\
\hline
\end{tabular}

\section{Introduction}

Arecanut or Betelnut is the kernel obtained as a main produce of arecanut palm (Areca catechu Linn) and it also have some other beneficial parts, such as husk, leaves and sheath which can be used for different purpose. Arecanut sheath is the raw materials obtained from the arecanut palm mainly used for commercial plate making purpose. Leaf sheath obtained from the farm are highly heterogeneous having variations in structure, shape and thickness. In certain regions of Kerala and Dakshina Kannada, leaf sheath is also used as cattle feed as an alternative to paddy straw by cutting of sheath into small pieces using kathi (sharp edged straight blade hand tool) and machets (Bavappa, et al., 1982).The available machinery for chop making have been tried to chop the arecanut sheath into suitable fodder size. However, due to its physical and biological characteristics of the arecanuts heath, none of them were found suitable to get desired size (Gaikwad and Bhargav, 2012). Hence, keeping the above factors in view, an attempt has been made to design, develop an arecanut sheath shredding machine for making arecanut sheath into suitable fodder size for animals.

\section{Materials and Methods}

\section{Design of arecanut sheath shredder}

The electric motor operated arecanut sheath shredder designed and fabricated for chopping 
of arecanut sheath used as a cattle fodder for animals. It consist of a main frame, shear plate, feeding chute, cylindrical cutterhead unit, feed roller unit and power transmission system. The overall dimensions of prototype of arecanut sheath shredder are $1000 \mathrm{~mm}, 500$ $\mathrm{mm}$ and $780 \mathrm{~mm}$ respectively in length, width and height.

\section{Selection of prime mower}

The selection of suitable power source is very important while developing any type of agricultural machine. So, the electric motor or diesel engine was selected as a power source which drives the chopping cutterhead unit carrying the knives in the arecanut sheath shredder.

It is evident from the literature that there exist a definite relationship between feed roller speed, cylinder cutterhead speed and number of knives for chopping arecanut sheath. Varsheny et al., (2004) according that, cylindrical cutterhead speed for 2 knives, 3 knives and 4 knives was varied as more than $600 \mathrm{rpm}, 500-600 \mathrm{rpm}$ and 400-500 rpm respectively. For getting the above speed, three size of $\mathrm{V}$-belt drive pulley with $\mathrm{B}$ section (8inch, 10 inch and 12 inch) can be used for power transmission.

In order to determine/select a suitable size of prime mover required for operating the arecanut sheath shredder machine at desired cylindrical cutterhead speeds, the trials were conducted in laboratory immediately after the design and development of arecanut sheath shredder machine. The cylindrical cutterhead placed on suitable frame by using bearings and appropriate speed ratios of drive were selected for obtaining cylindrical cutterhead speeds of $500 \mathrm{rpm}, 600 \mathrm{rpm}$ and $700 \mathrm{rpm}$. The single phase $3.73 \mathrm{~kW}$ electric motor with wattmeter was taken to study the power consumption at different cylindrical cutterhead speeds and feed roller speed, with a varying of number of knives (2, 3 and 4$)$ in the cylindrical cutterhead.

For changing the cylindrical cutterhead peripheral speed, the pulleys having diameter of $203.2 \mathrm{~mm}, 254 \mathrm{~mm}$ and $304 \mathrm{~mm}$ were used to get $18.33 \mathrm{~m} \mathrm{~s}^{-1}$ (700 rpm), $15.71 \mathrm{~m} \mathrm{~s}^{-1}$ (600 $\mathrm{rpm})$ and $13.10 \mathrm{~m} \mathrm{~s}^{-1}(500 \mathrm{rpm})$ and it is also changed feed roller peripheral speed $0.28 \mathrm{~m} \mathrm{~s}^{-1}$ (107.14 rpm), $0.36 \mathrm{~m} \mathrm{~s}^{-1}$ (138.5rpm) and 0.45 $\mathrm{m} \mathrm{s}^{-1}$ (175 rpm), respectively by using the pulley having a diameter of $355.6 \mathrm{~mm}, 330.2$ $\mathrm{mm}$ and $304.8 \mathrm{~mm}$. A pulley of $101.6 \mathrm{~mm}$ diameter was provided on electric motor which acts as prime mover.

The studies revealed that, the maximum power consumption of $1.46 \mathrm{~kW}$ at load condition was observed for a feed roller speed of $0.28 \mathrm{~m} \mathrm{~s}^{-1}$ and $18.33 \mathrm{~m} \mathrm{~s}^{-1}$ cylinderperipheral speed at 2 numbers of knives. Considering the losses in the power transmission system, a single phase $2.23 \mathrm{~kW}$ electric motor was selected as prime mover for operating arecanut sheath shredder.

The electric motor was mounted on the main frame by using two pairs of MS angles and provision was made to slide the motor to get desired tension on the belt. In between motor and MS angle frame, a wooden plank of 20 $\mathrm{mm}$ thick and 460mm length was placed in order to absorb the vibration offered by the motor during the operation. The isometric view, right view and top view of arecanut sheath shredder designed in solid works is shown in Figures 1, 2 and 3. The specification of arecanut sheath shredder is given in Table 1 .

\section{Design of shafts}

\section{Design of cylindrical cutterhead shafts}

The torque transmitted by the shaft was calculated by using formula suggested by Khurmi and Gupta (2006). 
$\mathrm{T}=\frac{\mathrm{P} \times 60}{2 \times \pi \times \mathrm{N}}$

Where,

$\mathrm{T}=$ Torque transmitted by the shaft, $\mathrm{N}-\mathrm{mm}$

$\mathrm{P}=$ Power, $\mathrm{W}$

$\mathrm{N}=$ rpm of shaft

$P=\frac{\left(T_{1}-T_{2}\right) \times V}{60}$

Where,

$\mathrm{T}_{1}=$ Tension on tight side of belt, $\mathrm{kg}$

$\mathrm{T}_{2}=$ Tension on slack side of belt, $\mathrm{kg}$

$\mathrm{V}=$ velocity of belt, $\mathrm{m} \mathrm{s}^{-1}$

$\mathrm{V}=\pi \times \mathrm{D} \times \mathrm{N}(1.3)$

Where,

$\mathrm{D}=$ Diameter of cutterhead large pulley, $\mathrm{m}$

$\mathrm{N}=$ Speed of cutterhead shaft, rpm

$\mathrm{V}=\pi \times 0.204 \times 700$

$\mathrm{V}=448.66 \mathrm{~m} \mathrm{~s}^{-1}$

$2238=\left(\mathrm{T}_{1}-\mathrm{T}_{2}\right) \times 448.66 / 60$

$\left(T_{1}-T_{2}\right)=2238 \times 60 / 448.66$

Where,

$\mathrm{T}_{1}=2 \mathrm{~T}_{2}$

$\mathrm{T}_{2}=293.3 \mathrm{~N}$

$\mathrm{T}_{2}=29.3 \mathrm{~kg}$

$\mathrm{T}_{1}=58.6$

$\mathrm{P}=(58.6-29.3) \times 448.66$

$\mathrm{P}=2149.14 \mathrm{~W}$
$\mathrm{T}=\frac{2149.14 \times 60}{2 \times 3.142 \times 700}$

$\mathrm{T}=29.31 \mathrm{~N}-\mathrm{m}$

$\mathrm{T}=29.31 \times 10^{3} \mathrm{~N}-\mathrm{mm}$

The torque transmitted by the shaft (T)

$\mathrm{T}=\frac{\pi}{16} \times \tau \times d^{3}$

Where,

$\tau=$ Torsional shear stress, MPa (for Mild Steel $\tau=42 \mathrm{MPa}$ Khurmi and Gupta, 2006)

$\mathrm{d}=$ diameter of the shaft, $\mathrm{mm}$

$29.31 \times 10^{3}=\frac{\pi}{16} \times 42 \times \mathrm{d}^{3}$

$\mathrm{d}^{3}=\frac{29.31 \times 10^{3} \times 16}{3.142 \times 42}$

$\mathrm{d}^{3}=19552.15$

$\mathrm{d}=26.94 \mathrm{~mm}$

The shaft diameter was selected as $30 \mathrm{~mm}$.

\section{Design of feed roller shaft}

The torque transmitted by the shaft was calculated by using formula suggested by Khurmi and Gupta (2006).

$\mathrm{T}=\frac{\mathrm{P} \times 60}{2 \times \pi \times \mathrm{N}}$

Where,

$\mathrm{T}=$ torque transmitted by the shaft, $\mathrm{N}-\mathrm{mm}$

$\mathrm{P}=$ power, $\mathrm{W}$

$\mathrm{N}=$ rpm of shaft 


$$
\mathrm{T}=\frac{1324 \times 60}{2 \times 3.142 \times 128.5}
$$

$\mathrm{T}=98.39 \mathrm{~N}-\mathrm{m}$

$\mathrm{T}=98.39 \times 10^{3} \mathrm{~N}-\mathrm{mm}$

The torque transmitted by the shaft $(\mathrm{T})$

$$
\mathrm{T}=\frac{\pi}{16} \times \tau \times d^{3}
$$

Where,

$\tau=$ torsional shear stress, MPa (for Mild Steel

$\tau=42 \mathrm{MPa}$ Khurmi and Gupta, 2006)

$\mathrm{d}=$ diameter of the shaft, $\mathrm{mm}$

$98.39 \times 10^{3}=\frac{\pi}{16} \times 42 \times \mathrm{d}^{3}$

$\mathrm{d}^{3}=11930.86$

$\mathrm{d}=22.8 \mathrm{~mm}$

The shaft diameter was selected as $25 \mathrm{~mm}$.

\section{Feeding chute}

The feeding chute is the component of arecanut sheath shredder, which receives the fodder and fed it to the feed rolls.

It is of in trapezoidal shape. The sheath was manually fed at the rate of one sheath at a time. The feeding chute was made from mild steel sheet (Ojha and Michael, 2003).

The minimum length of feeding chute shall be $900 \mathrm{~mm}$ to $1200 \mathrm{~mm}$ respectively (Kepner and Bainer, 1978). The overall dimensions of the feeding chute were $900 \mathrm{~mm} \times 550 \&$ $450 \mathrm{~mm} \times 100 \mathrm{~mm}$ length, top and bottom width and height of feeding chute, respectively.

\section{Shear plate}

Shear plates were provided at stationary edge against which the cutterhead knives shear the sheath and it also helps to hold the sheath. It is provided in between the feed roller and cutterhead knives. It is made from cast iron. The cutting clearance between shear plate and knives was adjusted in between 2-6 $\mathrm{mm}$ in order to maintain proper cutting action.

\section{Feed roller}

Feed roller is a device used to gather, compress and advance the arecanut sheath into the cylindrical cutterhead for chopping the sheath into suitable fodder sizes. Arecanut sheath shredder consists of two feed roller and their roll shaft shall be mounted on pedestrian bearings at one end and having spur gear attachment on the other end to transfer the horizontal speed of the driving gear to the driven gear. A pair of rollers aligned parallel to one another for admission of arecanut sheath in the lateral direction, a cylindrical cutterhead with knives whose motion is synchronized with that of the pair of rollers. The motion of the chopping machine is synchronized with that of the roller to ensure that the required sizes of sheath are cut from the arecanut sheath shredder. The lower feed roller and the upper feed roller has pyramid shape spikes mounted on periphery to strike on a sheath and provide a maximum holding ability with uniform size of cut.

The upper and lower feed roller should have relatively smaller diameters and be close to the cutting plane, so that long pieces will not be pulled through by the knife. The upper feed roller is spring loaded and have provision for several centimeters of vertical movement to accommodate varying amount of material. Action is positive, when the motion of the top roller and the chopping cylinder cutterhead are anticlockwise and that of the lower roller 
is in the clockwise direction. For the most positive feed, the feed roller speeds should be same. Changing the speed of the feed rollers can reduce or increase the length of cut of arecanut sheath. The overall dimensions of feed roller were $450 \mathrm{~mm}$ long and $50 \mathrm{~mm}$ diameter, respectively. The feed roller was made from cast iron.

Fig.1 Isometric view of arecanut sheath shredder designed in solid works

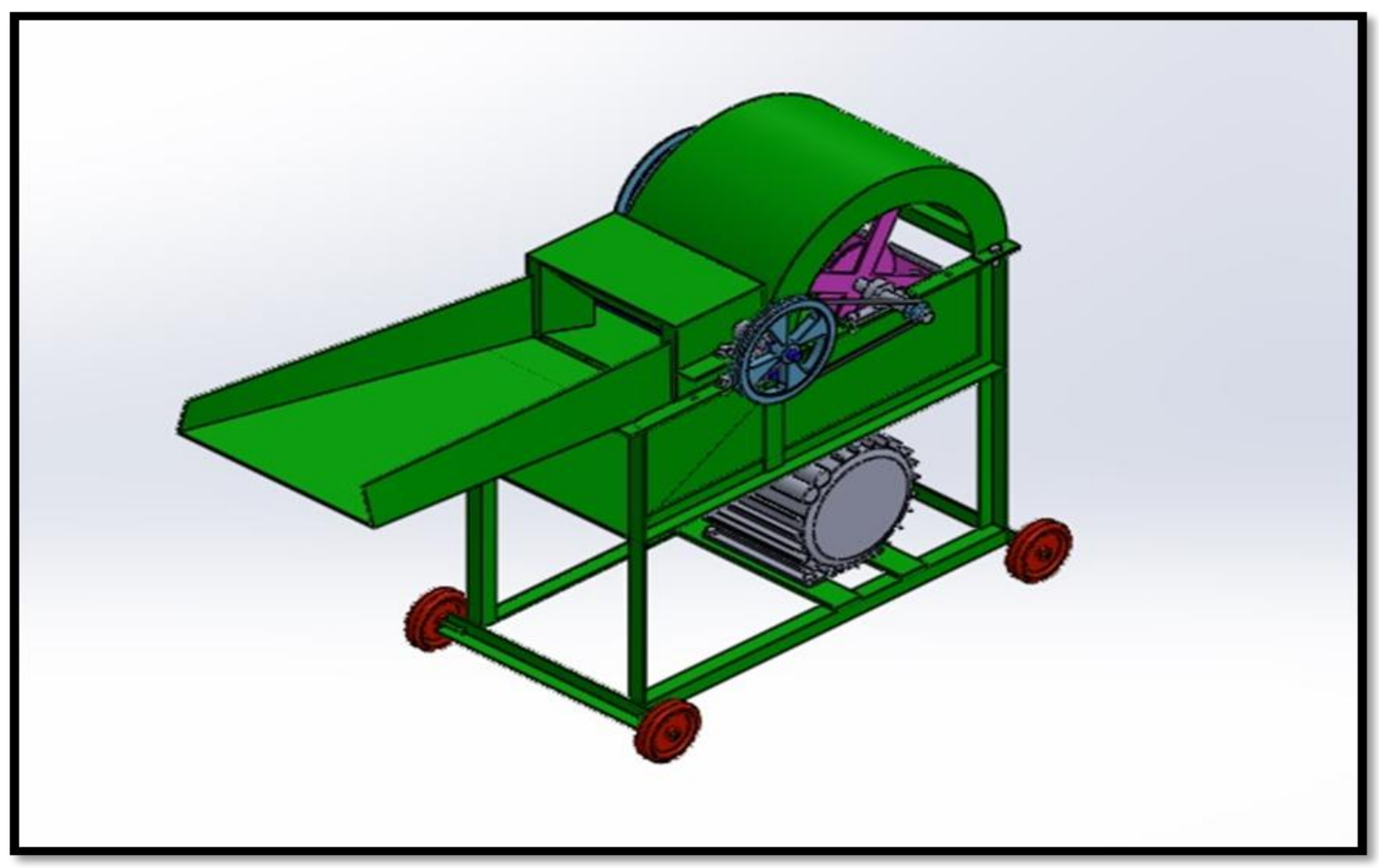

Fig.2 Right view of arecanut sheath shredder designed in solid works

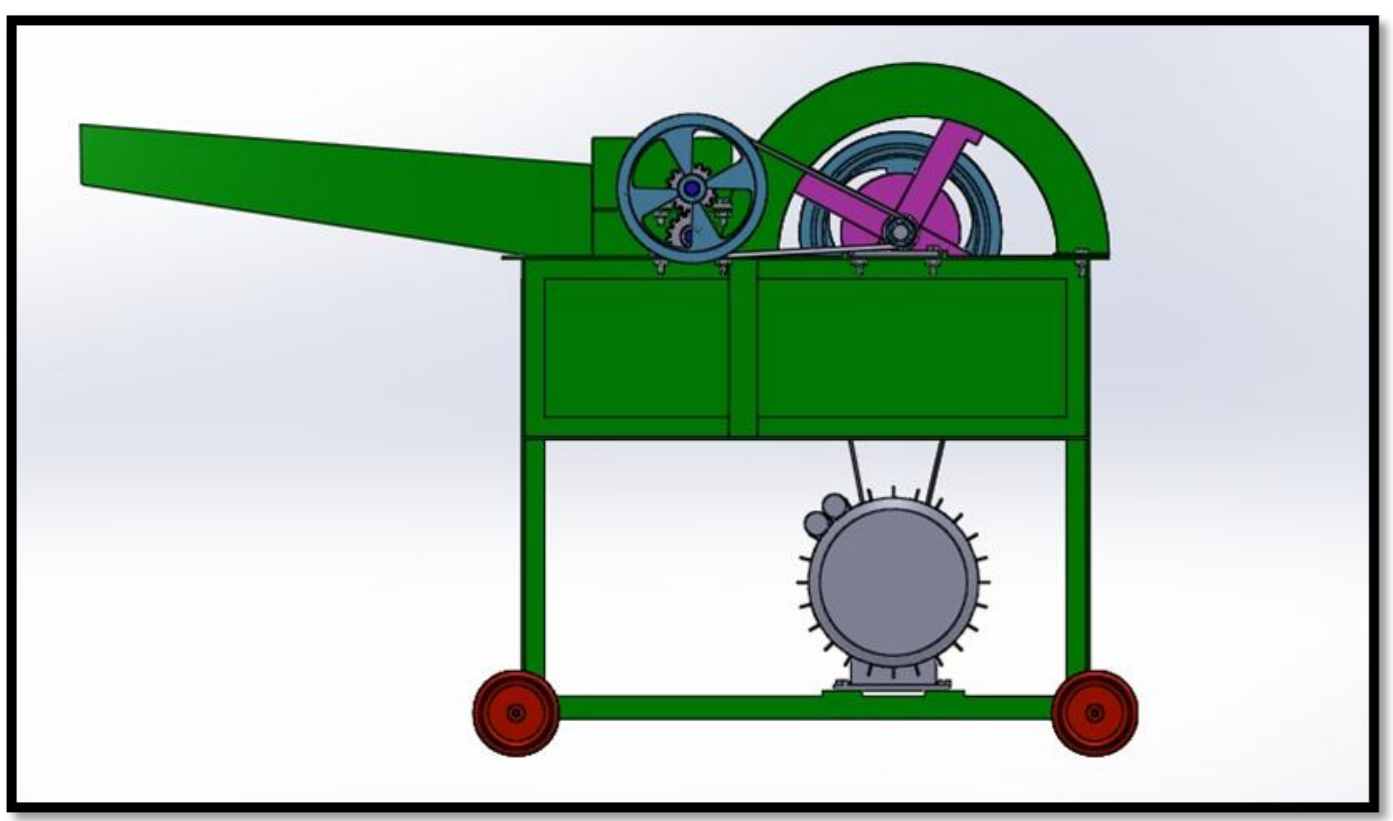


Fig.2 Right view of arecanut sheath shredder designed in solid works

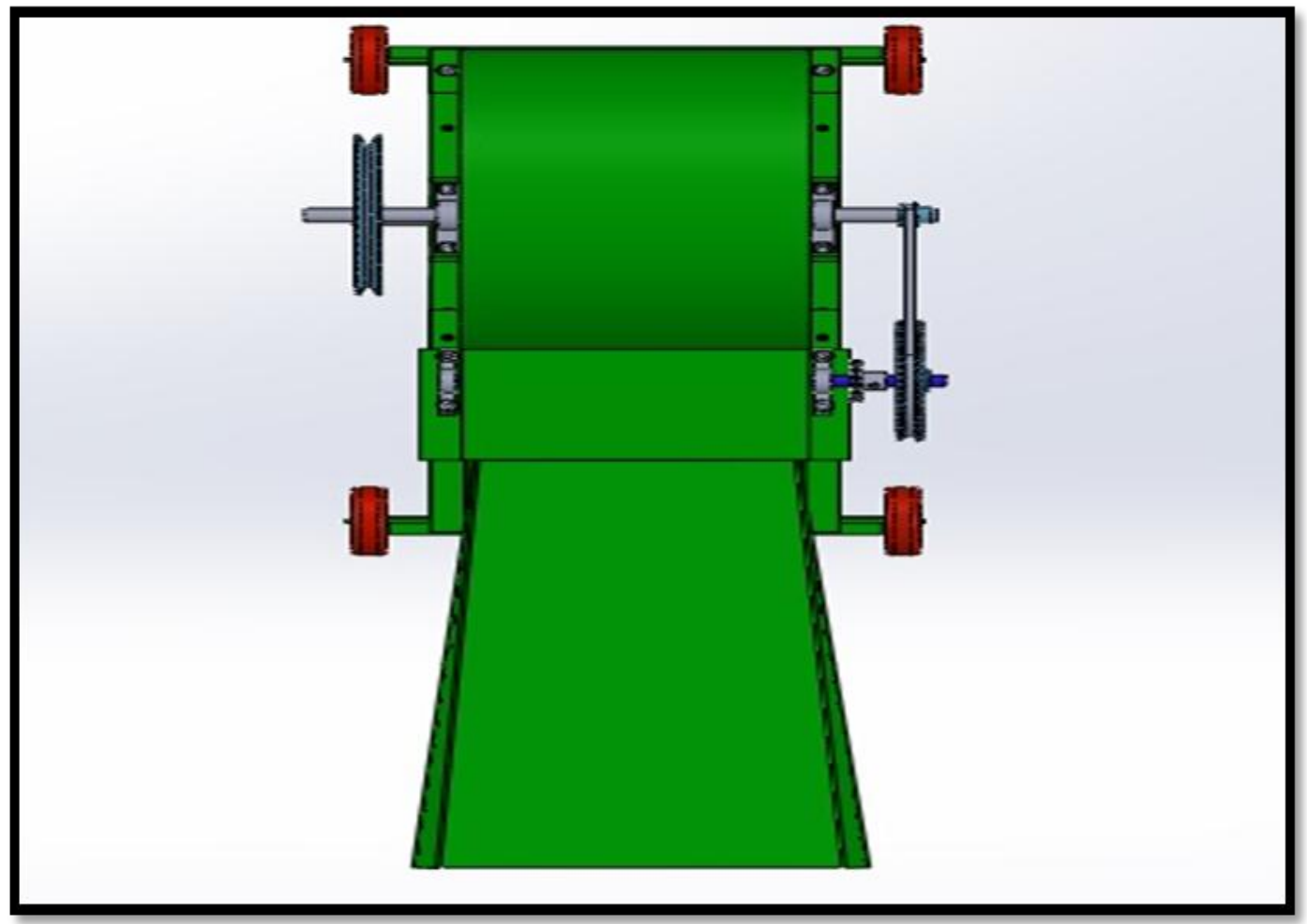

Fig.4 A view of fabrication of cylindrical cutterhead unit

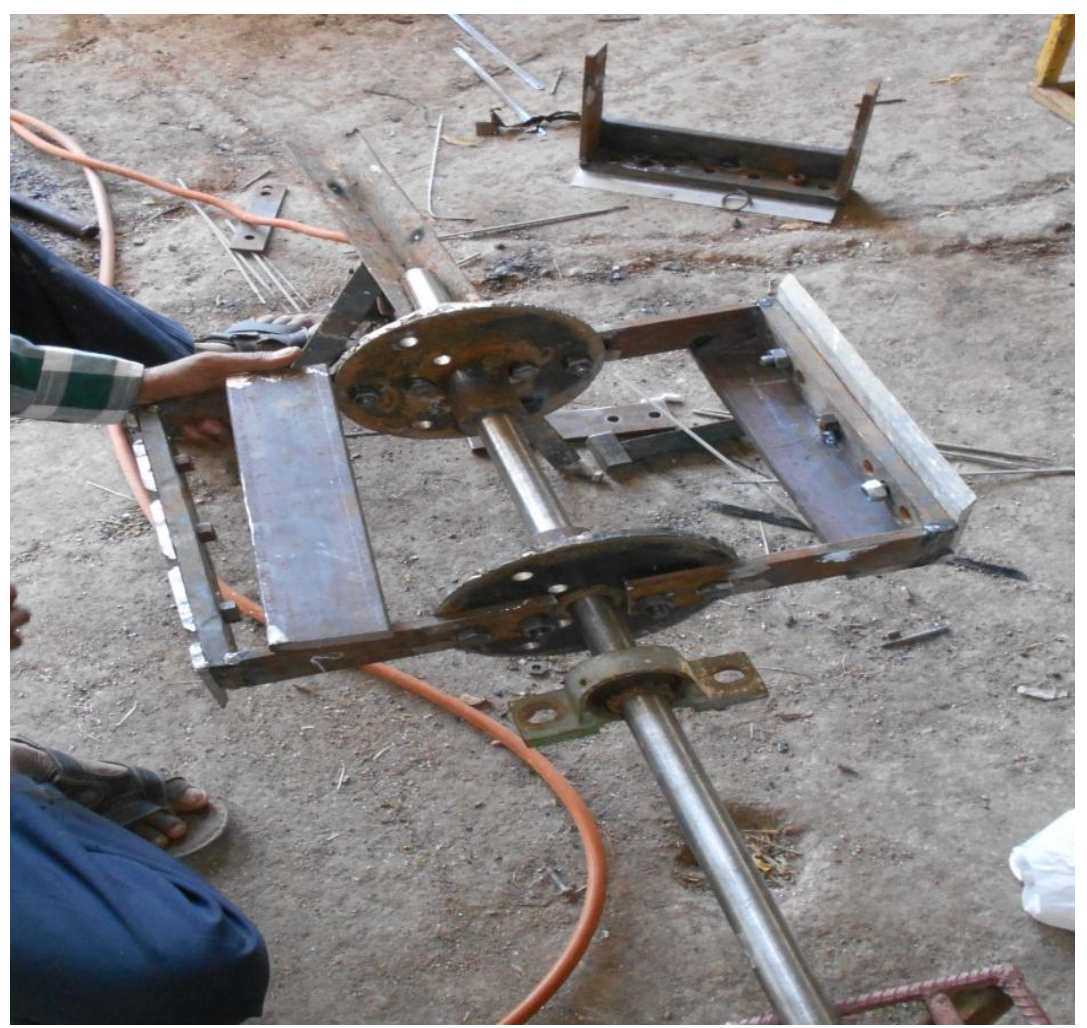


Fig.5 A view of assembly of cylindrical cutterhead unit in the main frame

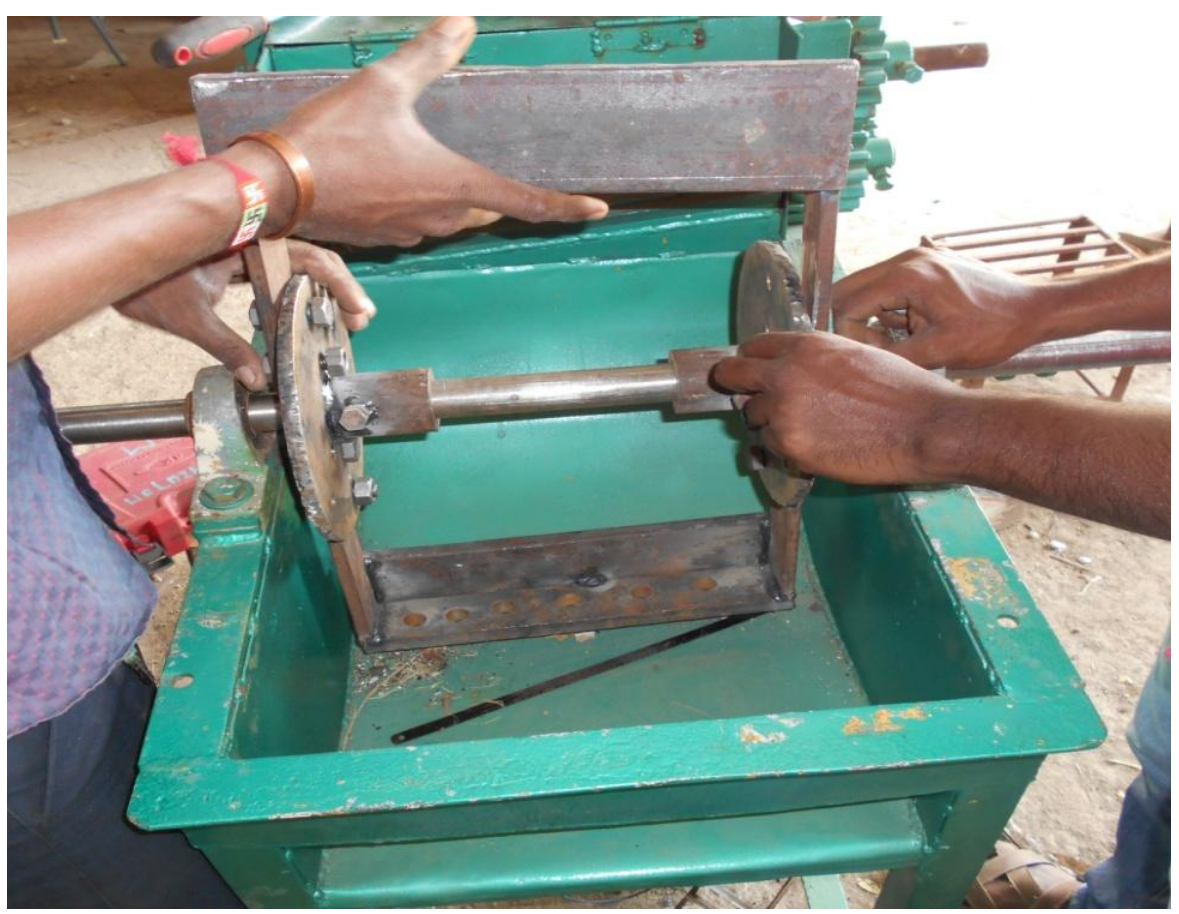

Fig.6 Block diagram of power transmission system

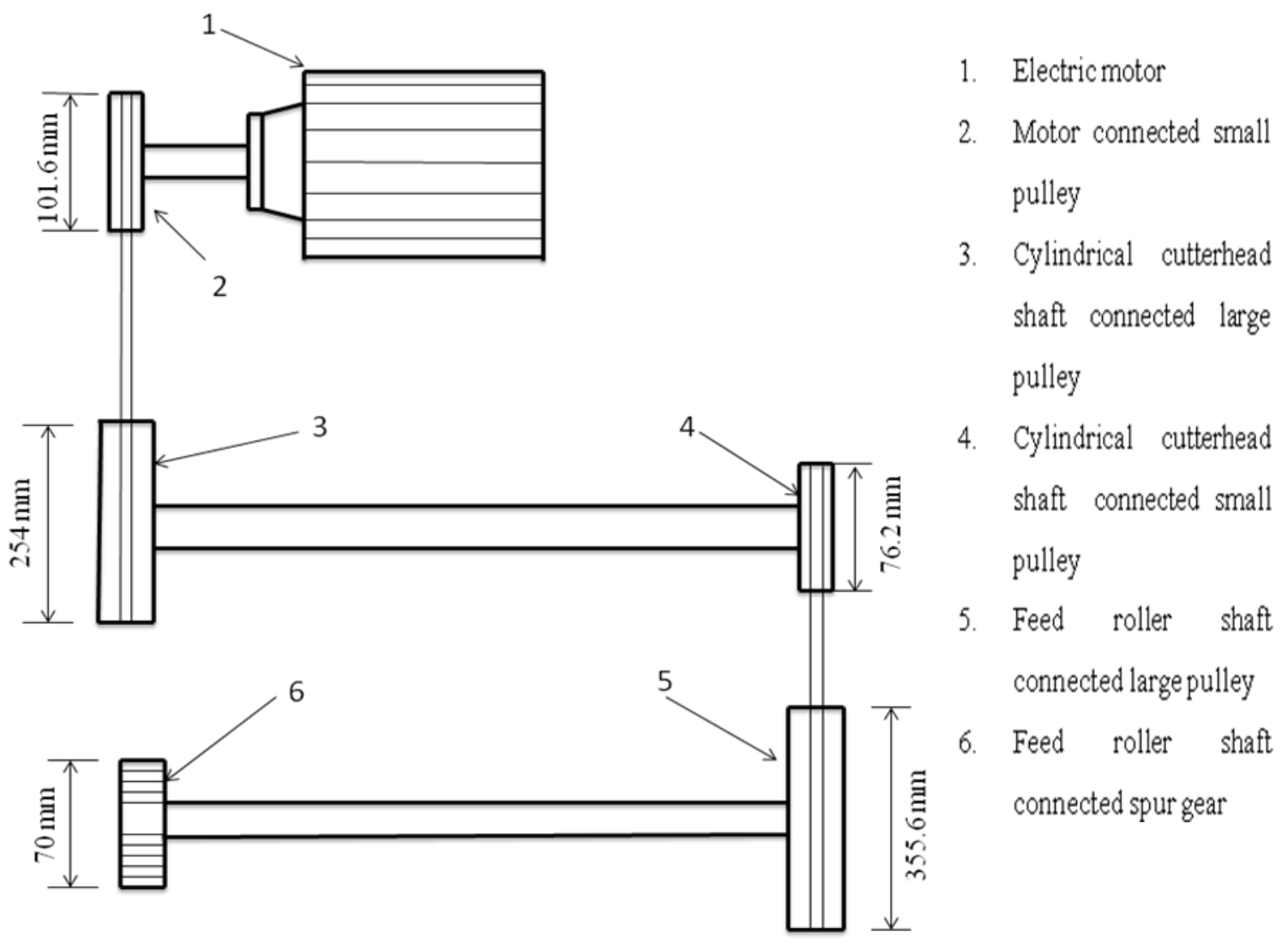


Table.1 The specifications of arecanut sheath shredder

\begin{tabular}{|c|c|c|}
\hline Sl. No & Components/parts & Shape/dimensions \\
\hline \multirow[t]{4}{*}{1} & Main frame & \\
\hline & Shape of the frame & Rectangular \\
\hline & Length $\mathrm{x}$ width $\mathrm{x}$ height, $\mathrm{mm}$ & $1000 \times 500 \times 780$ \\
\hline & Number of transport wheels & 4 \\
\hline \multirow[t]{10}{*}{2} & Chopping unit & \\
\hline & Cylindrical cutterhead (length $\mathrm{x}$ diameter), $\mathrm{mm}$ & $450 \times 520$ \\
\hline & Shape & Cylindrical \\
\hline & Type of knives & Straight \\
\hline & Number of knives varying on cylinder periphery & $2-4$ \\
\hline & Size of the knives (width $\mathrm{x}$ height $\mathrm{x}$ thickness), $\mathrm{mm}$ & $450 \times 85 \times 7$ \\
\hline & $\begin{array}{l}\text { The knives mounted on cylindrical cutterhead at an angle for } 2,3 \& 4 \text { number } \\
\text { of knives, degree }\end{array}$ & $90,120 \& 180$ \\
\hline & Diameter of the two MS plates used in centre of the cylinder, $\mathrm{mm}$ & 250 \\
\hline & Cylinder shaft (length $\mathrm{x}$ diameter), $\mathrm{mm}$ & $750 \times 31.75$ \\
\hline & Shape & Cylindrical \\
\hline \multirow[t]{12}{*}{3} & $\begin{array}{r}\text { Feeding unit } \\
\end{array}$ & \\
\hline & Feed roller (length $\mathrm{x}$ radius), $\mathrm{mm}$ & $450 \times 25$ \\
\hline & Shape & Cylindrical \\
\hline & $\begin{array}{l}\text { Number of pyramid shaped spikes mounted over the upper and lower feed } \\
\text { roller }\end{array}$ & 630 \\
\hline & $\begin{array}{l}\text { Size of pyramid shaped spikes mounted over the upper and lower feed roller, } \\
\mathrm{mm}\end{array}$ & $10 \times 10$ \\
\hline & Feed roller shaft (length $\mathrm{x}$ diameter, $\mathrm{mm}$ ) & $690 \times 25$ \\
\hline & Shape & Cylindrical \\
\hline & $\begin{array}{l}\text { Feeding chute } \\
\text { length, mm } \\
\text { top and bottom width, mm } \\
\text { height, } \mathrm{mm}\end{array}$ & $\begin{array}{c}900 \\
350-400 \\
100\end{array}$ \\
\hline & Shape & Trapezium \\
\hline & Shear plate(Length $\mathrm{x}$ width, $\mathrm{mm}$ ) & $450 \times 60$ \\
\hline & Shape & Rectangular \\
\hline & Recommended clearance between fixed shear plate and rotating knives & $2-6 \mathrm{~mm}$ \\
\hline \multirow[t]{9}{*}{4} & $\begin{array}{l}\text { Power transmission system } \\
\end{array}$ & \\
\hline & Size of the motor drive pulley (groove $\mathrm{x}$ diameter), $\mathrm{mm}$ & $1 \times 101.6$ \\
\hline & Size of shaft (diameter), $\mathrm{mm}$ & 25.4 \\
\hline & Size of the driven pulley on cylinder shaft (groove $\mathrm{x}$ diameter), $\mathrm{mm}$ & $\begin{array}{l}1 \times(203,254 \& \\
304)\end{array}$ \\
\hline & Size of the drive pulley on cylinder shaft (groove $\mathrm{x}$ diameter), $\mathrm{mm}$ & $1 \times 76.2$ \\
\hline & Size of the driven pulley on feed roller shaft (groove $\mathrm{x}$ diameter), $\mathrm{mm}$ & $\begin{array}{c}1 \times(355.6,330.2 \& \\
304.8)\end{array}$ \\
\hline & Number of spur gear used at one end of the feed roller shaft & 2 \\
\hline & Number of teeth on the each spur gear mounted on the feed roller shaft & 16 \\
\hline & Number of pedestal bearing used in cutterhead shaft and feed roller shaft & 4 \\
\hline \multirow[t]{5}{*}{5} & $\begin{array}{ll}\text { Prime mower } \\
\end{array}$ & \\
\hline & Type & $\begin{array}{l}\text { Single phase } \\
\text { Induction motor }\end{array}$ \\
\hline & Frame of the electric motor (length $\mathrm{x}$ spacing of holes of motor base), $\mathrm{mm}$ & $500 \times 40$ \\
\hline & Electric motor capacity, $\mathrm{kW}$ & 2.23 \\
\hline & Rated speed, rpm & 1430 \\
\hline
\end{tabular}




\section{Cylindrical cutterhead}

\section{Shape}

The cylindrical cutterhead is most commonly used in power operated machines. In this study arecanut sheath shredder consist of a cylindrical cutterhead for chopping arecanut sheath. It has a cylindrical shape cutterhead with knives on a revolving cylinder to chopping materials into required size. It is mounting on the shaft. The straight knives were used as a sheath cutting element, because the power operated machines use only straight blades (knives). The cylindrical cutterhead is most commonly preferred than flywheel type cutterhead, because cylinder diameter is much smaller than flywheel diameters, therefore more cuts per minute can be obtained without unnecessarily high peripheral speeds and the accompanying excessive power requirements. Rigidity of the cutting components, necessary for maintaining close clearances between the knives and the shear bar, is easier to obtain than on a flywheel cutterhead. There is a less damage to a cylinder type cutterhead if a foreign object is fed into it. Therefore a cylindrical type cutterheadwas developed and evaluated for chopping of arecanut sheath. The overall dimensions of cutterhead were $520 \mathrm{~mm}$ diameter and $450 \mathrm{~mm}$ length.The view of the fabrication of cylindrical cutterhead unit and assembly of cylindrical cutterhead unit was placed in the main frame of arecanut sheath shredderis shown in Figures 4 and 5.

\section{Direction of rotation}

The direction of rotation of cylindrical cutterhead in arecanut sheath shredder machine is similar like chaff cutter machine. The cutting action of a shredder machine is positive, when the direction of rotation of the top roller and the chopping cylinder cutterhead are anticlockwise and that of the lower roller is in the clockwise direction.

\section{Knives}

The knife is an important component in the cylindrical cutterhead of arecanut sheath shredder. In this study, straight knives can be used for chopping of arecanut sheath. The knives were mounted parallel to the cylinder axis to get better performance. The length of the knives was kept equal to the length of the cylinder. To obtain a clean cut, knives must operate close to the shear plate without striking (Ojha and Michael, 2003). In this shredder design two to four knives can be varied for decreasing or increasing the chop length. It is made from high carbon steel (Gagadishwar, 2010). The knives can be added or removed from the cylindrical cutterhead to increase or decrease the chopping length of sheath.

The knives can be sharpened without being removed from the cylinder. While sharpening the knives with a grinder, care should be taken not to spoil the bevel of the edge and also not to get it overheated by excessive grinding. The number of knives vary on cylindrical cutterhead is $2-4$. Angle between two, three and four number of knives are $180^{\circ}, 120^{\circ}$ and $90^{\circ}$. The cutting knives are made of high carbon steel. The length, width and thickness of cutting knives are 450, 85 and $7 \mathrm{~mm}$, respectively.

\section{Design of power transmission system}

V-belt drive system of B-cross section was selected for power transmission as this system works satisfactorily at linear speed from less than $0.5 \mathrm{~m} \mathrm{~s}^{-1}$ up to $20 \mathrm{~m} \mathrm{~s}^{-1}$. The selection of the pulley and belts for cylindrical cutterhead shaft and feed roller shaft were made depend on the rated power developed by electric motor, rated speed of motor drives pulley, 
cylindrical cutterhead diameter, cylindrical cutterhead speed and feed roller speed. The block diagram of power transmission system is shown in Figure 6.

The electric motor operated arecanut sheath shredder designed and fabricated for chopping of arecanut sheath used as a cattle fodder for animals. It consist of a main frame, shear plate, feeding chute, cylindrical cutterhead unit, feed roller unit and power transmission system. The machine components were fabricated in the laboratory. The developed shredder was operated by $3 \mathrm{hp}$ electric motor. The overall dimensions of prototype of arecanut sheath shredder are $1000 \mathrm{~mm}, 500$ $\mathrm{mm}$ and $780 \mathrm{~mm}$ respectively in length, width and height. It was observed that the cost of operation of arecanut sheath shredder was 195 $\mathrm{Rsh}^{-1}$ and cost of chopped arecanut sheath was $1.5 \mathrm{Rs} \mathrm{kg}^{-1}$. Breakeven point and payback period were $181 \mathrm{~h}^{\text {annum }}{ }^{-1}$ and 1.34 year, respectively.

\section{References}

Bavappa, K. V. A., Nair, M. K. and Kumar T. P., 1982. The Arecanut Palm, Central Plantation Crops Research Institute,
Kasargod, ICAR Publication. pp. 272273.

Gagadishwar, S., 2010. Elements of agricultural engineering $4^{\text {th }}$ Ed., Standard publishers distributors., NaiSarak, New Delhi, pp. 374-375.

Gaikwad, B. B., and Bhargav, V. K., 2012. Size reduction machine for arecanut sheath- enabling alternative animal fodder generation. J. Agrotechnol., 1 (2): 64.

Kepner, R. A., Bainer, R and Barger, E. L., 1978. Principles of farm machinery $3^{\text {rd }}$ $E d$., The AVI publishing company inc., USA, p. 368-371.

Khurmi, R., and Gupta, J., 2006. A text book of machine design $8^{\text {th }} E d$., Eurasia publishing house pvt ltd., Ramnagar, New Delhi. p. 511-512.

Ojha, T. P., and Michael A. M., 2011. Principles of Agricultural Engineering Vol. I. Reliance industries pvt. ltd., New Delhi, pp. 467-476.

Varsheny, A. C., Tiwari, P. S., Suresh, N. and Mehta, C. R., 2004. Data book for agricultural machinery design. Central institute of agricultural engineering, Nabibagh, Bhopal, pp. 405-108.

\section{How to cite this article:}

Shashikumar, D.J. Shrinivasa, M. Anantachar and Veerangouda, M. 2017. Conceptual Design of Arecanut Sheath Shredder. Int.J.Curr.Microbiol.App.Sci. 6(10): 1920-1929. doi: https://doi.org/10.20546/ijcmas.2017.610.231 